\title{
Entrepreneurial Orientation for Sustainable Competitive Advantage and Risk Management: Evidence from Government-Linked Companies in Malaysia
}

\section{Jamaliah Said*}

Accounting Research Institute, Universiti Teknologi MARA, Shah Alam, Selangor, Malaysia E-mail: jamaliah533@salam.uitm.edu.my

\section{Md. Mahmudul Alam}

School of Economics, Finance \& Banking, College of Business, Universiti Utara Malaysia, Sintok, Kedah, Malaysia

E-mail: rony000@gmail.com

\section{Nur Nadiah Zulkarnain}

Faculty of Accountancy, Universiti Teknologi MARA, Shah Alam, Selangor, Malaysia E-mail: nurnadiah.zul@gmail.com

\section{Nik Herda Nik Abdullah}

Faculty of Accountancy, Universiti Teknologi MARA, Shah Alam, Selangor, Malaysia E-mail: nik_herda@yahoo.com

\footnotetext{
* corresponding author
}

\section{Citation Reference:}

Said, J., Alam, M.M., Zulkarnain, N.N., and Abdullah, N.H.N. 2016. Entrepreneurial Orientation for Sustainable Competitive Advantage and Risk Management: Evidence from Government-Linked Companies in Malaysia. International Journal of Applied Business and Economic Research, Vol. 14(10), pp. 6529-6544. [Online Link] 


\title{
Entrepreneurial Orientation for Sustainable Competitive Advantage and Risk Management: Evidence from Government-Linked Companies in Malaysia
}

\begin{abstract}
This study is an attempt to assess the status of the current level of entrepreneurial orientation among the Government-Linked Companies (GLCs) in Malaysia. This study collected primary data based on a set of questionnaire survey among 134 executives and managers of GLCs in Malaysia. The data were collected based on opinions of the seven factors of entrepreneurial orientation practices by using the five-point Likert scale. The data were analysed using descriptive statistics. Further, the reliability of the data was tested using Cronbach's alpha test, the validity of the data was tested by checking the normality test through skewness and kurtosis, and the consistency of the data was tested using factor analysis. On an average, $70.9 \%$ of the respondents agreed that they focus on these factors of entrepreneurial orientation. The federal owned GLCs place more emphasis on entrepreneurial orientation than the state owned GLCs. This study suggests improving the practices of entrepreneurial orientation of GLCs in Malaysia by emphasizing on recognizing individual risk takers for their willingness to champion new projects, whether it eventually turns out to be successful or not, encouraging employees to take calculated risks with new ideas, considering the term "risk taker" as a positive attribute for people in the organization, and supporting many small and experimental projects by realizing that some will undoubtedly fail.
\end{abstract}

Key Words: entrepreneurial orientation, government0linked companies, sustainable competitive advantage, Malaysia

\section{Introduction}

The resource-based view theory (RBV) focuses on transforming valuable resources of the organization to assist in achieving its goals (Barney, 1991). RBV states that organizations that are able to use or fully utilize their resources, such as raw materials, skills, etc., will have the opportunity to gain competitive advantages over their competitors (Grant, 1991), and offer sustainable competitive advantage to the organization (Macfarlane, 2014). Competitive advantage is a situation where the organization is able to create or improve its product and make it superior to the competitors' product. Sustainable competitive advantage will help the organization cope with the changes in the environment and stay successful in the future (Ketchen \& Short, 2014) by achieving long-term competitive advantage, which will be costly and difficult to imitate by their competitors (Papulova \& Papulova, 2006).

Sustainable competitive advantage can bring many advantages, as it is a powerful source for the organization to achieve superior performance and create value for the organization (Gupta \& Benson, 2011). According to Barney (1991), organizations could create competitive advantages by obtaining valuable, rare, inimitable resources, and capabilities. Obtaining such resources will lead to value creation and sustainability in the organization. Kraaijenbrink \& Spender (2011) also state that without value creation, the organization would have no added value and thus, there would be no reason for the organization to exist in the market. Value creation can improve the performance of the organization by maximizing earnings per share, ensure high levels of operational effectiveness, and remain competitive (Gholami, 2011). This will indirectly help the organization to implement strategies to improve their efficiency and competitiveness (Porter, 1997). 
However, there is no guarantee that all of the resources will lead to competitive advantage or value creation. This is because, according to Kraaijenbrink and Spender (2011), people may perceive values differently. What one perceives as valuable may not be the same for another person. Moreover, due to globalization and the increase in competition, it is hard for organizations to sustain and cope with the rapid changes in the environment. Therefore, organizations must be able to offer or create something new in order to differentiate themselves from their competitors. According to Prieto and Revilla (2006), organizations that are able to offer something different in the market have the potential to achieve superior performance and are able to create value for their organization.

Therefore, in order to ensure the sustainability of some government agencies, the government of Malaysia decided to privatize the companies, which led to the formation of the Government-Linked Companies (GLCs). GLCs are defined as companies that achieve the primary commercial objective of the Malaysian government (Khazanah, 2014) and the Malaysian government has a direct controlling stake in these companies (OECD, 2013). The controlling stake refers not only to the percentage of their ownership, but also their direct or indirect influence in the appointment of directors and senior management officers. They also make major decisions such as contracting awards, strategizing, restructuring, financing, and acquisition and divestments through Government-Linked Investment Companies (GLICs). In other words, GLCs are controlled by the Malaysian government via GLICs, Khazanah, Ministry of Finance Inc. (MOF), Employees Provident Fund (EPF), and Bank Negara Malaysia (BNM). ${ }^{1}$

GLCs cover a wide spectrum of economic activities from infrastructure, telecommunication, agriculture, to financial services. Thus, GLCs play an important role in the operation of every commercial concern in Malaysia and contribute significantly towards improving the quality of life for the public (Abdullah, 2007; Razak, 2012). GLCs are a corporate entity that may be a private company or a public listed company. However, GLCs only account for about five percent of the total companies in Bursa Malaysia (formerly known as Kuala Lumpur Stock Exchange or KLSE), GLCs' market capitalization amounts to RM 232 billion, which is more than half of Malaysia's Gross Domestic Product (Md Zin \& Sulaiman, 2011).

The main objective of an organization is to improve the performance and the business process of the organization so that they will be as competitive as other companies in the market (Aivazian, Ge, \& Qiu, 2005). According to Phua (2001), the government economic planners believe that the privatization of public services would bring many advantages to the country. This is in line with past evidence that agrees privatization could increase the efficiency of the organization, greater utilization of growth opportunities, reduce the administrative and financial burdens of the Malaysian government, and increase Bumiputera participants in the corporate sector (Nambiar, 2009). However, there are issues in which GLCs are labelled as underperforming, as they deal with dual objectives, which are to make profits and fulfil social obligations. This has given GLCs an adverse image.

Therefore, to overcome the underperformance issue, in May 2004, the government introduced the GLC Transformation Programme. The main objective of this programme is to improve the performance of GLCs and all corporate sectors so that they would perform

\footnotetext{
${ }^{1}$ Retrieved from http://www.khazanah.com.my
} 
successfully. This transformation program is important as it is one of the journeys for the organization to achieve Vision 2020. Quite a few GLCs have been successful in implementing the programme, such as Telekom Malaysia, Malaysian Airport Holding Berhad (MAHB), and United Engineering Malaysia (UEM) Group Berhad. These companies have turned out to be more profitable and have been recognized internationally (Md Zin \& Sulaiman, 2011).

However, past studies still show that GLCs lack value creation compared to nonGLCs (Entebang, 2010; Mohamad \& Said, 2011; Lau \& Tong, 2008; Feng, and Sun, \& Tong, 2004; Razak et al., 2011). Muslim, Hafiz, and Fekri Ali (2012) state that GLCs have suffered from recurring poor firm performances due to the lack of value creation in their organization, which has made them come under the government's scrutiny. Razak et al. (2011) find that non-GLCs' performances are better than GLCs in terms of their corporate governance and other forms of specific characteristics, which makes them create more value than GLCs. This is because GLCs do not focus too much on maximizing profits, as they are also concerned about contributing towards nation building (Lau \& Tong, 2008).

Several GLCs are unable to create value and thus suffer from poor performances such as the Malaysian Airline System (MAS) and Proton Holding Berhad. Hence, GLCs need to put in extra initiatives to create value so that they will be able to meet the requirements and expectations of the government and at the same time, be able to increase and add value to their products, services, and business performance (Lawler \& Mohrman, 2013; Aziz et al., 2015a,b,c; Said et al., 2015, 2016). Khazanah (2014) states that GLCs are expected to improve and enhance their value creation by focusing on sustainable practices and execution from 2015 onwards. Currently, GLCs, especially the G202 companies, have started to focus on sustainable practices to achieve long-term value creation. However, some GLCs tend to undermine the importance of sustainable practices as they have several goals to accomplish. Moreover, there are currently limited researches done on value creation in Malaysian GLCs (Lau \& Tong, 2008).

Under this circumstance, this study investigates the practices of sustainable competitive advantage strategies among different categories of Government-Linked Companies (GLCs) in Malaysia. Entrepreneurship is considered one of the most important features for an organization to gain sustainable competitive advantage, boost performances, and create value for the organization (Entebang, 2010; Lyon, Lumpkin, \& Dess, 2000). Without the existence of entrepreneurial orientation, there will be no new ideas and the implementation of innovation is almost impossible. Koe (2013) states that entrepreneurial orientation leads to value creation as it improves the performance of the organization, growth, market share, and stakeholder satisfaction. Past studies have found that organizations that perform corporate entrepreneurship obtain higher profits (Omar \& Ishak, 2013; Che Omar, Mohamad, \& Abdul Kader, 2012; Entebang, Abu Mansor, \& Puah, 2006; Antoncic \& Hisrich, 2003; Ferreira, 2002). In addition, entrepreneurship plays an important role in emerging economies as it could increase productivity, improve best practices, create new products and services, and enhance competitiveness (Entebang, Abu Mansor, \& Puah, 2006; Bruton, Ahlstrom, \& Obloj, 2008).

\footnotetext{
${ }^{2}$ G20 is the selection of large GLCs, which are controlled by GLICs under the GLCT Programme and is used as a proxy for performance of the GLCs. However, the G20 currently consists of only 17GLCs due to mergers, demergers, divestments, and other corporate exercises over the years.
} 
The role of entrepreneurship and its effect on GLCs' value creation remains unexplored, because GLCs have limited autonomy and flexibility compared to private companies, such as having limited resources (Entebang, 2010). Some GLCs refuse to deal with risky investments as they feel that their normal business activities are already risky and challenging (Omar \& Ishak, 2013). In addition, according to Zahra, Ireland, and Hitt (2000), most GLCs do not engage in entrepreneurial-oriented behavior because of the limited resources and capabilities. However, in GLCs, entrepreneurial orientation is important, as it leads to the renewal or creation of new businesses or products and supports innovation. Moreover, the formation of GLCs has led to entrepreneurship behaviour among the public and government-related agencies as privatization provides an environment that encourages entrepreneurial activities (Antoncic \& Hisrich, 2003). The Prime Minister of Malaysia, YAB Dato' Sri Najib Tun Haji Abdul Razak, states that innovation and entrepreneurship has the ability to create competitive advantages, value creation and improve the quality of life of the society (Science2action, 2011). In addition, by recognizing the importance of innovation and entrepreneurial orientation, the government has decided to create a more entrepreneurial environment so that organizations would be engaged in a high-tech based undertaking and have the ability to meet the demands of the market. According to Koe (2013), GLCs need to be more entrepreneurial than bureaucratic, as it will enable organizations to create value and improve their performances. Therefore, this study investigates the practices of entrepreneurial orientation as a strategy of sustainable competitive advantage among different categories of Government-Linked Companies (GLCs) in Malaysia.

\section{Methodology}

\subsection{Sampling and Data Collection}

The data for this study are collected based on a questionnaire survey among 134 executives and managers of GLCs in Malaysia. The survey was conducted between February and April of 2015 .

\subsection{Measurements of Variables}

This study uses seven parameters to measure the practices of entrepreneurial orientation adopted from Hornsby, Kuratko, and Zahra (2000). The practices of entrepreneurial orientation are measured based on the management support for corporate entrepreneurship. The factors are as follows:

E1 Individual risk takers are often recognized for their willingness to champion new projects, whether it eventually turns out to be successful or not.

E2 Employees are often encouraged to take calculated risks with new ideas.

E3 The term "risk taker" is considered a positive attribute for people in the organization.

E4 Organization supports many small and experimental projects realizing that some will undoubtedly fail.

E5 Organization is actively searching for business opportunities.

E6 Key executives are risk-takers in exploring business opportunities.

E7 The top management of the organization considers rapid growth as a dominant goal.

The respondents are asked to compare all the practices of innovation in their organization against their competitors in the same industry for at least three years. The 
questionnaire uses a five-point Likert rating scale ranging from 1 (strongly disagree) to 5 (strongly agree).

\subsection{Data Analysis}

The data are analysed using descriptive statistics. Factor analysis is used to measure the consistency of the data. Further, the reliability of the data is tested using the Cronbach's alpha test. Finally, the data validity is tested by checking the normality of data through skewness and kurtosis.

\section{Analysis and Finding}

\subsection{Demographic Information}

The study collected a few demographic data of the respondents, which include gender, age, job position, level of education, number of years working in the GLC, type of industry, and the number of employees in the organization. A summary of the demographic information is given in Table 1.

Table 1: Demographic information of the respondents

\begin{tabular}{|c|c|c|c|}
\hline Demographic Profile & & Frequency & Percentage $(\%)$ \\
\hline \multicolumn{4}{|l|}{ Gender: } \\
\hline & Male & 55 & 41.0 \\
\hline & Female & 79 & 59.0 \\
\hline \multicolumn{4}{|l|}{ Age Group: } \\
\hline & Under 30 years & 32 & 23.9 \\
\hline & 30 to 40 years & 51 & 38.1 \\
\hline & 41 to 50 years & 33 & 24.6 \\
\hline & 51 years and above & 18 & 13.4 \\
\hline \multicolumn{4}{|l|}{ Level of education: } \\
\hline & SPM/MCE/Certificate & 1 & 0.7 \\
\hline & Diploma & 19 & 14.2 \\
\hline & University degree & 104 & 77.6 \\
\hline & Professional qualification & 10 & 7.5 \\
\hline \multicolumn{4}{|l|}{ Job Position: } \\
\hline & Top management & 7 & 5.2 \\
\hline & Middle management & 68 & 50.7 \\
\hline & Lower management & 59 & 44.0 \\
\hline \multicolumn{4}{|l|}{ Type of industry: } \\
\hline & Service & 53 & 39.6 \\
\hline & Manufacturing & 13 & 9.7 \\
\hline & Others & 68 & 50.7 \\
\hline \multicolumn{4}{|l|}{ Owner Type of GLCs: } \\
\hline & State & 40 & 30 \\
\hline & Federal & 86 & 64 \\
\hline & Other & 8 & 6 \\
\hline \multicolumn{4}{|c|}{ Number of years working in GLCs: } \\
\hline & Less than 1 year & 12 & 9.0 \\
\hline & 1 to 3 years & 26 & 19.4 \\
\hline & 4 to 5 years & 16 & 11.9 \\
\hline
\end{tabular}


No. of employees:

$\begin{array}{lcc}\text { Less than } 100 & 17 & 12.7 \\ 100 \text { to } 500 & 26 & 19.4 \\ 501 \text { to } 1000 & 9 & 6.7 \\ \text { More than } 1000 & 82 & 61.2\end{array}$

Among the respondents, 59\% are female and $41 \%$ are male. Most of the respondents are in the 30-40 years age group, which comprises $38 \%$ of the total respondents. Majority of the respondents, $77.6 \%$, have a minimum first degree.

Among the respondents, $50.7 \%$ are in the middle management position. In terms of the type of industries, $39.6 \%$ of the respondents are involved in the service sector followed by $9 \%$ in the manufacturing sector, while most of them are in other sectors such as broadcasting. Among the GLCs considered in this study, 64\% are owned by the federal government and $30 \%$ by the state governments.

About half of the respondents $(59.7 \%)$ have been working for more than 5 years in GLCs. Based on the number of employees, $61.2 \%$ of the respondents work in large organizations that consist of more than 1000 employees.

\subsection{Descriptive Analysis}

The study measures the practices of entrepreneurial orientation in GLCs using seven variables. Among the respondents, on an average, $70.9 \%$ agree that they exercise these factors of entrepreneurial orientation and $6 \%$ mention that they do not practise them (Table 2).

Table 2: Score of the factors of entrepreneurial orientation among the GLCs in Malaysia

\begin{tabular}{ccccccccc}
\hline Score & E1 & E2 & E3 & E4 & E5 & E6 & E7 & All Average \\
\hline 1 & 3 & 1 & 4 & 7 & 2 & 3 & 3 & 1 \\
2 & 13 & 9 & 12 & 11 & 5 & 6 & 6 & 7 \\
3 & 32 & 41 & 39 & 37 & 19 & 28 & 26 & 31 \\
4 & 58 & 60 & 55 & 56 & 64 & 67 & 69 & 77 \\
5 & 28 & 23 & 24 & 23 & 44 & 30 & 30 & 18 \\
\hline Disagree (1-2) & 16 & 10 & 16 & 18 & 7 & 9 & 9 & 8 \\
Agree (4-5) & 86 & 83 & 79 & 79 & 108 & 97 & 99 & 95 \\
Disagree\%(1-2) & $11.9 \%$ & $7.5 \%$ & $11.9 \%$ & $13.4 \%$ & $5.2 \%$ & $6.7 \%$ & $6.7 \%$ & $6.0 \%$ \\
Agree\%(4-5) & $64.2 \%$ & $61.9 \%$ & $59.0 \%$ & $59.0 \%$ & $80.6 \%$ & $72.4 \%$ & $73.9 \%$ & $70.9 \%$ \\
Average & 3.71 & 3.71 & 3.62 & 3.57 & 4.07 & 3.86 & 3.87 & 3.78 \\
Maximum & 1 & 1 & 1 & 1 & 1 & 1 & 1 & 1 \\
Minimum & 5 & 5 & 5 & 5 & 5 & 5 & 5 & 5 \\
Std. Dev. & 0.98 & 0.86 & 0.98 & 1.04 & 0.87 & 0.89 & 0.89 & 0.77 \\
Factor Loading & 0.87 & 0.85 & 0.80 & 0.75 & 0.75 & 0.74 & 0.68 & \\
\hline
\end{tabular}

Among all of the factors of entrepreneurial orientation, the highest mean score is 4.07 for the factor of looking for new business opportunities (E5), and the lowest mean score is 3.57 for the factor of supporting many small and experimental projects realizing that some will undoubtedly fail (E4) (Table 2). The average mean value is 3.78. There is scope to improve the overall entrepreneurial orientation by emphasizing on the factors that are below the average score such as individual risk takers need to be recognized for their willingness to champion new projects, whether it eventually turns out to be successful or not (E1), 
employees need to be encouraged to take calculated risks with new ideas (E2), the term "risk taker" needs to be considered a positive attribute for people in the organization (E3), and many small and experimental projects are needed to be supported by realizing that some will undoubtedly fail (E4).

Table 3: Score of the factors of entrepreneurial orientation according to the types of GLCs in

\begin{tabular}{|c|c|c|c|c|c|c|c|c|c|}
\hline \multicolumn{10}{|c|}{ Malaysia } \\
\hline & tegory & E1 & E2 & $\mathbf{E 3}$ & E4 & E5 & E6 & E7 & Total \\
\hline \multirow{3}{*}{$\begin{array}{l}\text { GLC } \\
\text { Type }\end{array}$} & State & 3.43 & 3.55 & 3.35 & 3.40 & 3.70 & 3.60 & 3.58 & 3.51 \\
\hline & Federal & 3.81 & 3.78 & 3.71 & 3.65 & 4.23 & 3.94 & 3.99 & 3.87 \\
\hline & Other & 4.00 & 3.75 & 4.00 & 3.63 & 4.13 & 4.25 & 4.13 & 3.98 \\
\hline \multirow{3}{*}{$\begin{array}{c}\text { Industry } \\
\text { Type }\end{array}$} & Service & 3.72 & 3.70 & 3.58 & 3.57 & 4.17 & 3.87 & 4.00 & 3.80 \\
\hline & Manufacturing & 3.62 & 3.62 & 3.31 & 3.23 & 3.46 & 3.62 & 3.23 & 3.44 \\
\hline & Other & 3.72 & 3.74 & 3.71 & 3.65 & 4.10 & 3.90 & 3.90 & 3.82 \\
\hline
\end{tabular}

Overall, the federal owned GLCs place more emphasis on the factors of entrepreneurial orientation than the state owned GLCs (Table 3). Among the factors of entrepreneurial orientation, both state and federal owned GLCs emphasize the most on looking for new business opportunities (E5), while the state owned GLCs emphasize the least on considering the term "risk taker" as a positive attribute for employee (E3), and federal owned GLCs emphasize the least on supporting many small and experimental projects realizing that some will undoubtedly fail (E4).

The GLCs engaged in the service sector are more focused on entrepreneurial orientation than other sectors (Table 3). These service sector GLCs emphasize the most on looking for new business opportunities (E5), and emphasize the least on supporting many small and experimental projects realizing that some will undoubtedly fail (E4). The GLCs engaged in the manufacturing sector place the most emphasis on recognizing individual risk takers for their willingness to champion new projects, whether it eventually turns out to be successful or not (E1), encouraging employees to take calculated risks with new ideas (E2) and risk-taking by key executives in exploring business opportunities (E6), and the least emphasis on supporting many small and experimental projects realizing that some will undoubtedly fail (E4) as well as considering rapid growth as the dominant goal by top management (E7).

\subsection{Diagnostic Test}

\subsubsection{Consistency Test}

The factor analysis provides the consistency of these variables for entrepreneurial orientation measurement. The factor loadings for all the variables are more than 0.6 (Table 2). The ranges of the loading value of the factor is from 0.68 (E7) to 0.87 (E1). This indicates that all of the seven variables are good to measure the practices of entrepreneurial orientation in the GLCs of Malaysia.

\subsubsection{Normality Test}

The normality test is performed to check the distribution of data. According to Pallant (2013), the normality of the data can be described by using the skewness and kurtosis tests, where the data can be considered normally distributed when the kurtosis value is between -3 to 3 and 
the skewness value is below zero. For the factors of entrepreneurial orientation, the skewness value is -0.746 , and the kurtosis value is 1.20 , which are within the acceptable range. Therefore, the data can be considered as normally distributed.

\subsubsection{Reliability Test}

The Cronbach's alpha (Table 4) value on entrepreneurial orientation is 0.89 , which indicates the reliability of the questions is excellent (George \& Mallery, 2003). The eigenvalue for the test indicates that the factor used in entrepreneurial orientation explains the $60.6 \%$ variance. The Kaiser-Meyer Olkin test indicates a value greater than 0.6 at 0.869 (Chi-Square $=508, \mathrm{p}$ $<0.000)$. Therefore, the sample is adequate to be used in the factorial analysis. Generally, the test supports the variables of entrepreneurial orientation in this study.

Table 4: Reliability test for the factors of entrepreneurial orientation

\begin{tabular}{lr}
\hline Cronbach's Alpha & 0.888 \\
Eigen \% variance & 60.611 \\
\hline \% of variance & 60.611 \\
Kaiser-Meyer-Olkin Measure of Sampling Adequacy & 0.869 \\
Bartlett's Test of Sphericity Approx. Chi-Square & 508.874 \\
Bartlett's Test of Sphericity Sig. & 0.000 \\
\hline
\end{tabular}

\section{Conclusion and Recommendation}

Malaysia has targeted to achieve Vision 2020 to become a developed nation, but there are many more steps to be taken in importing value creation in GLCs. This study measured the status of the current practices of entrepreneurial orientation among different categories of GLCs in Malaysia by assessing seven related factors. The factor analysis provided the consistency of these seven variables for entrepreneurial orientation measurement. $70.9 \%$ of the respondents admitted to exercising these seven factors of entrepreneurial orientation, and their average score was 3.78 out of a 5 scale.

Therefore, there is scope for improving the practices of entrepreneurial orientation by the GLCs. Hence, the GLCs need to put in extra initiatives to create value so that they will be able to meet the requirements and expectations of the government and at the same time, be able to increase and add value to their products, services and business performance (Lawler \& Mohrman, 2013). Overall, GLCs should emphasize on recognizing individual risk takers for their willingness to champion new projects, whether it eventually turns out to be successful or not, encourage employees to take calculated risks with new ideas, consider the term "risk taker" as a positive attribute for people in the organization, and support many small and experimental projects by realizing that some will undoubtedly fail. However, the state owned or federal owned GLCs and GLCs engaged in manufacturing or service sectors should emphasize on more focused areas for their improvement.

\section{Acknowledgement}

We would like to express our sincere gratitude to the Accounting Research Institute (ARI), Universiti Teknologi MARA, Shah Alam, and the School of Economics, Finance \& Banking, College of Business, Universiti Utara Malaysia, Sintok, Kedah in collaboration with the Ministry of Education Malaysia (MOE) in providing financial assistance to carry out this research project. The research was supported under the Fundamental Research Grant Scheme (FRGS). 


\section{References}

Abdullah, N.H.N. \& Said, J. (2015a). Enhancing the Governance of Government Linked Companies via Strategic Management Accounting Practices and Value Creation, Procedia Economics and Finance, 28: 222 - 229.

Aivazian, V. A., Ge, Y., \& Qiu, J. (2005). Can corporatization improve the performance of state-owned enterprises even without privatization? Journal of Corporate Finance, 11(5): 791-808.

Antoncic, B., \& Hisrich, R. D. (2003). Privatization, Corporate Entrepreneurship, and Performance: Testing a Normative Model. Journal of Development Entrepreneurship, 8(3): 197-218.

Aziz, M.A.A., Rahman, H.A., Alam, M.M., \& Said, J. (2015b). Enhancement of the Accountability of Public Sectors through Integrity System, Internal Control System and Leadership Practices: A Review Study. Procedia Economics and Finance, 28: 163-169.

Aziz, M.A.A., Said, J. \& Alam, M.M. (2015a). An Assessment of the Practices of Leadership Quality in the Public Sectors of Malaysia. Procedia Economics and Finance, 31: 909918.

Aziz, M.A.A., Said, J., \& Alam, M.M. (2015c). Assessment of the Practices of Internal Control System in the Public Sectors of Malaysia. Asia-Pacific Management Accounting Journal, 10(1): 43-62.

Barney, J. B. (1991). Firm Resources and Sustained Competitive Advantage. Journal of Management, 17: 99-120.

Bruton, G. D., Ahlstrom, D., \& Obloj, K. (2008). Entrepreneurship in Emerging Economies: Where Are We Today and Where Should the Research Go in the Future. Entrepreneurship Theory and Practice, 3(1): 1-14.

Entebang, H. (2010). Entrepreneurial Orientation and Corporate Entrepreneurship Performance of Government-Linked Companies in Malaysia. Queen's University Belfast, Belfast.

Entebang, H., Abu Mansor, S., \& Puah, C.-H. (2006). Corporate Entrepreneurial Orientations in State Owned Enterprises in Malaysia. FEB Working Paper Series.

Feng, F., Sun, Q., \& Tong, W. H. S. (2004). Do government-linked companies underperform? Journal of Banking \& Finance, 28(10): 2461-2492.

Ferreira, J. (2002). Corporate Entrepreneurship: A Strategic and Structural Perspective. New England Journal of Entrepreneurship, 4(1): 59-71.

George, D., \& Mallery, P. (2003). SPSS for Windows step by step: A simple guide and reference. 11.0 update. BrJHaematol (Vol. 11.0 updat, p. 231). Retreived from http://wps.ablongman.com/wps/media/objects/385/394732/george4answers.pdf

Gholami, S. (2011). Value Creation Model through Corporate Social Responsibility (CSR). International Journal of Business and Management, 6(9): 148-154.

Grant, R. M., (1991). The Resource-Based Theory of Competitive Advantage: Implication for Strategy Formulation. California Management Review, 33(3): 114-135.

Gupta, N. J., \& Benson, C. C. (2011). Sustainability and Competitive Advantage: An Empirical Study of Value Creation. Competition Forum, 9(1): 121-136.

Hornsby, S. J., Kuratko, D. F., \& Zahra, S. A. (2002). Middle Managers' Perception of The Internal Environment for Corporate Entrepreneurship: Assessing a Measurement Scale. Journal of Business Venturing. 17(3) :253-273.

Ketchen, D., Short, S. (2014). Resource-Based Theory. Mastering Strategic Management. Retrieved from http://catalog.flatworldknowledge.com/bookhub/reader/3085?e=ketchen_1.0-ch04_s01 
Khazanah, (2014). GLCs Delivering High Performance and Catalysing Inclusive Growth. Retrieved from http://www.khazanah.com.my/docs/140610\%20GLC\%20Progress\%20Review.pdf

Koe, W.-L. (2013). Entrepreneurial Orientation (EO) and Performance of GovernmentLinked Companies (GLCs). Journal of Entrepreneurship Management and Innovation, 9(3): 21-41.

Kraaijenbrink, J., \& Spender, J., C.,. (2011). Theories of the Firm and their Value Creation Assumptions. Annual International Conference of the Strategic Management Society, 69 November, Miami, US.

Lau, Y. W., \& Tong, C. Q. (2008). Are Malaysian Government Linked Companies (GLCs) creating value? International Applied Economics and Management Letters, 1(1):9-12.

Lawler, E. E., \& Mohrman, A. S. (2013). Sustainability: What Should Boards Do? Centre for Effective Organization. CEO Publication (January), Marshall School of Business, University of Southern California.

Lyon, D. W., Lumpkin, G. T., \& Dess, G. G. (2000). Enhancing Entrepreneurial Orientation Research: Operationalising and Measuring a Key Strategic Decision Making Process. Journal of Management. 26(5): 1055-1085.

Macfarlane, M. A. (2014). Sustainable Competitive Advantage for Accountable Care Organizations. Journal of Healthcare Management. 59(4): 263-71.

Md Zin, N., \& Sulaiman, S. (2011). Government-linked Companies Blue Book (GLCs Blue Book) as a complement to Balanced Scorecard (BSC) in the Government-Linked Companies transformation program. IACSIT Press, 1. Kuala Lumpur.

Mohamad, N.H., \& Said, F. (2011). Efficiency and innovation in selected Malaysian government-linked companies for the period 2003 to 2008. African Journal of Business Management. 5(25): 10259-10270.

Muslim, H. S. M., Hafiz, M. A. R., \& Fekri Ali, M. S. (2012). Corporate governance and earnings management in Malaysian government linked companies. Asian Review of Accounting, 20(3): 241-258.

Nambiar, S. (2009). Revisiting Privitisation in Malaysia: The Importance of Institutional Process. Asian Academy of Management Journal. 14(2): 21-40.

OECD (2013), Education at a Glance 2013: OECD Indicators, OECD Publishing.

Omar, A. R. C., \& Ishak, S. (2013). Organization's Entrepreneurial Behaviors: A Study on Malaysian State Government Links Companies (SGLCS) Practices. Asian Social Science, 9(8). 87-95

Omar, A. R. C, Mohamad, M. R., \& Abdul Kader, R. (2012). Entrepreneurship Orientation and Malaysian State-Owned Enterprises: The Management Challenges. $3 r d$ International Conference on Business and Economic Research (3rd ICBER 2012) Proceeding, 12-13 March, Bandung, Indonesia.

Pallant, J. (2013). A Step by Step Guide to Data Analysis Using SPSS program. $5^{\text {th }}$ ed., Allen \& Unwin, Crows Nest, N.S.W.

Papulova, E. \& Papulova, Z. (2006). Competitive strategy and competitive advantages of small and midsized manufacturing enterprises in Slovakia. ELeader. Slovakia: International Leadership and Networking Conference.

Phua, K. L. (2001). Corporatization and Privatization of Public Services: Origins and Rise of a Controversial Concept. Akademika, 58 (Januari): 45-57. Retrieved from http://ejournals.ukm.my/akademika/article/view/2966/1891

Porter M.E. (1997). Competitive Strategy, Measuring Business Excellence, 1(2):12-17.

Prieto, I. M., \& Revilla, E. (2006). Learning capability and business performance: a non-financial and financial assessment. The Learning Organization, 13(2): 166-185. 
Razak, J.A. (2012). Government-linked Companies Transformation Programme to Spur Change. Retrieved from http://kperspectives.khazanah.com.my/Get_To_Know_Us-@ Government-linked_Companies_Transformation_Programme_to_Spur_Change.aspx

Razak, N. H. A., Ahmad, R, \& Joher, H. A. (2011). Does government linked companies (GLCs) perform better than non-GLCs? Evidence from Malaysian listed companies. Journal of Applied Finance \& Banking, 1(1): 213-240.

Said, J., Alam, M.M., and Aziz, M.A. 2015. Public Accountability System: Empirical Assessment of Public Sector of Malaysia. Asian Journal of Scientific Research, 8(2): 225-236.

Said, J., Alam, M.M., Khalid, M. (2016). Relationship between Good Governance and Integrity System: Empirical Study on the Public Sector of Malaysia. Humanomics. Forthcoming.

Science2action (2011). S2A: Perdana Menteri gesa rakyat Malaysia Membudayakan Keusahawanan Berasaskan Teknologi. Retrieved March 8, 2015 from http://www.science2action.my/index.php/media-centre/press-release

Zahra, S. A., Ireland, R. D., \& Hitt, M. A. (2000). Privatization and entrepreneurial transformation: Emerging issues and a future research agenda. Academy of Management Review, 25(3): 509-524 